\title{
Transformation of Correlation between Ethnic, Civic and Religious Components of the Personal Identity at the Beginning of the XXI century in Russia
}

\author{
Svetlana G. Maximova ${ }^{1}$, Oksana E. Noyanzina ${ }^{1}$, Anastasiya A. Gorbunova ${ }^{1}$, \\ Daria A. Omelchenko ${ }^{1}$, Maxim B. Maximov ${ }^{1}$ \\ ${ }^{1}$ The Altai State University, Barnaul, Russia
}

\begin{abstract}
This article analyzes the current structure of the identity of the population of Russia. The results of empirical studies of the population of 9 regions of Russia by the questionnaire are presented. Particular attention is paid to the ratio of ethnic, civic and religious components of the individual identity. The results of sociological studies show a high degree of importance to the residents of the regions of social differentiation on different grounds. The authors note that at present the main importance is the identification of the population with the citizens and the local community. At the same time, expressed ethnic identification of the population is not an obstacle for the formation of the all-Russian civic identity. It is emphasized that the religious factor is now a less important base of identification than ethnic or civic affiliation. On the basis of these studies it concluded that the different types of identity are not competing or mutually exclusive; on the contrary, they are the basis for the integration of the individual in numerous social communities formed for various reasons.
\end{abstract}

Key words: identity, ethnic identity, civic identity, religious identity, ethnic group, nationality.

\section{Introduction}

A problem of correlation between different types of identity (civic and ethnic, first of all) is one of the central discussions of contemporary social humanitarian knowledge. Some researchers point out the necessity of formation of a unite all-Russian identity to keep the security and unity of the country. For example, E. Eryomina marks out the competition between regional-ethnic identity and national (civic) identity in situations of the weakening or crisis of nation identity, so such situations my create threat to the solidarity in the country [1]. Others analyse opportunities of positive combination of these two types of identities. Thus, L. Drobizheva points out these identities as less competing for the majority of social groups, they may be combined as in positive way (they become the resource of active life position and activity attitudes) as in negative way (they enforce the hostility to the surrounding and the search for the enemy) [2].

A notion of 'identity' firstly emerged in works of D. Hume (1996). It became widely reflected in psychological, anthropology, political and sociological theories. According to English psychologist H. Tajfel (1986), social identity is 'the part of Self-concept of individual, that emerge from understanding of own group membership together with value and emotional significance of the group [3], i.e. individual's self-identification with certain community.

Several basic approaches to the research of social identity could be highlighted: symbolic interactionism, cognitive theory of social identity and constructivist theory.

As for psychoanalytic approach [4], identity understood as internal continuity of a personality. Significant input of the given theory is in recognition of variability of identity and description of mechanisms of its formation through interiorization of values, goals and convictions, either conscious or unconscious [5].

In symbolic interactionism [6], [7] social identity acts as the mean of delimitation against other people and instrument of integrity with society, at the same time. Mechanisms of identity formation determined because of socialization [8], assimilation of Self-representations of the 'generalized other, and roles, prescribed by social structure, but caused by certain personal features of an individual [7].

Thus, according to the theory of 'reflected or looking-glass self' by Charles Horton Cooley, selfidentification depends on imaginations of others about him/her in process of social interaction, first [7]. In G. 
Mead opinion, identity determined by attitudes of the 'generalized other' - averaged image of representatives of social groups, which his/she tends to belong [9]. The preposition to formation of identity is development of ability to 'take the attitudes of others'. According to E. Goffman's (2003) theory of Frames, construction of selfpresentation of social subject determined by its personal characteristics and social position, which determines the system of norms and necessity to follow them. In this way, social identity in these theories understood us a result of internalization of self-image in attitudes of the others by a subject, perceived in social interactions.

The last decades in Russia connected with the negotiation of consequences of the "explosion of identity" after the Soviet Union break out and solution of ethnic-political problems of national republic in the structure of the state. An evident dominance of ethnic differentiation in Russian society and weak all-national identity became the main consequence.

However, comparative analysis of data of sociological researches of the beginning of 1990-2000 years fix the dynamics in correlation between ethnic and civic identity. In particular, we mark out the growth and stability of all-Russian identifications, in the Russians dominant regions, especially [2]-[3], [10]. However, as some researches show us, several territories specified by strong ethnic identity of population, besides they reveal differences in the identification process of different ethnic groups. For example, V. Avksentyev and B. Aksyumov pointed out, that in the South of Russia civic and ethnic identities do not alternative, but they compete with each other [11].

Thus, at present the ethnic factor plays significant role in public consciousness. By all these, highly marked ethnic identity if characteristic not only for residents of national republic, but also for residents of border regions in whole. Such regions lay on the clash of geographic, political, economic, and ethnic-cultural and confession borders [12].

The other important aspect of the question is the close connection between ethnic and confessional identities. As a number of researches mark out, confessional factor became often included into contemporary ethnicpolitical processes, and ethnic-confessional identity became the mass one [10], [13]. All these let us to speak about risks because of the contradiction between some confessions, in the Christian and Islam world, in particular.

All these argue the acuteness of study of the correlation between civic, ethnic, and religious components of identity, dynamics of its transformations. Absolutely evident, that multi ethnic character of the modern society is the important factor of formation of Russian identity as a result of search for balance between civic, state and ethnic aspects of identity in Russia [14], [15]. Each identities as the ethnic and as the civic one, play certain functions, which are necessary for normal functioning of the personality and society, because they are important components of social identity in whole. If one of them became changed, a number of negative consequences may occur [16].

\section{Methods}

For the purpose of the study of the formation and revelation of civic and ethnic identity we realized sociological research among population of 9 border regions of Russia. The research was conducted with the questionnaire method, sampling - 4437 respondents at the age of 15-75 years. In a result of analysis we determined the peculiarities of identification structure of population of border regions of Russia, manifestation and correlation of civic, ethnic and religious components of the identity.

In sociological concept by P. Sztompka [17] the circles of the trust, characterizing society, are considered. The first circle - the very close people: family, close friends; the second one - the circle of direct contacts: neighbors, colleagues, friends by interests; the second circle - city, district: the fourth circle - area, region and republic. If the problems come out of the local government than contacts with the fourth circle become wider. And, the fifth circle - country, state, native sovereignty: here the all-national laws, rules of the game and means of enforcement are created. It is accepted, that in totality all these turn people to society, civil nation.

But we should mention that respondent makes the choice of the identity basing on free understanding. According to S. Moskovichi, our consciousness structured by types of identification matrix with many identifications (age, gender, family, professional, civic, ethnic, religious, ant others). The most significant identifications (leading, basic) can be determined among them. Such classifications were used in researches of 
V. Yadov, E. Damilova, L. Drobizheva [18], [10]. These authors, together with the question "How are you I the first way? Only the Russian; The Russian, dominantly; Only the Tatar; The Tatar, dominantly; both, but the Russian dominantly" tried to estimate the level of all-state identity in correlation with regional membership. Nevertheless, as it was revealed later [19], the considered identities are not static and univariate, they change sense and hierarchy.

In our research the structure of identities constructed from respondents' self-determination with the following communities: "Russian citizens", "residents of the city, village", "residents of region, oblast, Republic", "people of my generation", "people of my profession", "my coreligionists", "people of my prosperity" and "people of close political opinion". Simultaneously we tried to reveal the extent of "manifestation", "accent" of the identity.

\section{Discussion}

We asked respondents to determine the own proximity with the specified communities to obtain the structure of social identities of contemporary Russian population in regions.

Distribution of answers on the question "Do you fell proximity with the specified communities? In which extent?" shows, that respondents fell close to the community of Russian citizens first of all ("in considerable extent" $77.6 \%$, "in small extent" $18.2 \%$ of respondents).

Local and regional identities became highly significant for respondents. $75.9 \%$ of respondents feel themselves as residents of own city or village "in a great extent", $18.8 \%$ - "in a small extent"; as residents of own region $-72.1 \%$ and $22.3 \%$ correspondingly.

National (ethnic) identity is on the fourth place in the identification matrix: $68.0 \%$ of respondents feel proximity to representatives of own nationality "in a great extent", 23.1\% - "in a small extent". Further, according to the significance, are the generation identity (59.9\% and $28.8 \%$ correspondingly), professional (49.1\% and $30.8 \%$ correspondingly), religious (46.3\% and $28.8 \%$ correspondingly), social ( $43.1 \%$ and $34.6 \%$ correspondingly) and political identities (36.0\% and $29.4 \%$ correspondingly).

Thus, the most manifested and distributed form of social identity nowadays is the identity with Russian citizens. Ethnic identity revealed as not significant as the civic, regional and local identities.

Our results correlate with data by L. Drobizheva and V. Yadov. Since the disintegration of the USSR, ethnic identity became the "island" of stability, but the other identities (social-status and etc.) changed very fast. Thus, in 1998 no less than $90.0 \%$ of respondents identified themselves as a part of ethnic group, first of all. And only $50.8 \%$ identified themselves as the Russians. Since that time a new state identity became formation in conditions of frustrations, connected with the break-up of the Soviet Union, transformation of social structure, activation of national movements. Of course, here identities based on something stable and habitual - ethnic, regional became the base.

Further, then the national identity of the Soviet times ("Soviet people") destroyed, ethnic identity grew up and realized compensatory functions. Since the end of 1990s and from the beginning of the XXI century traditional role of Russian government as constructive and consolidating force in the Russian identity became to be understood again.

We may suppose the existence of the specifics in identity of different (inclining in number) ethnic groups. We compared the group of respondents, determined themselves as the Russians, and the group of other (nonRussian) nationality. Date from the Table 1 let us conclude about considerable proximity with different social communities of the Russian-speaking population. We assume them as the post integrated into Russian society group of population. The same indexes are lower among representatives of other ethnic groups, except the group of religious non-Russian respondents. Respondents, who are the strong believers, have evidently manifested national identity, than representatives of non-Russian ethnos. Thus, religion plays significant role in the life of non-Russian citizens. We suppose the adaptation difficulties of representatives of ethnic minorities in conditions of Russian multi nationality. 
TABLE I: Distribution of answers to the question

"Do you fell proximity with representatives of your ethnos? In which extent?", "in considerable extent", \%.

\begin{tabular}{lcc}
\hline \multicolumn{1}{c}{ Community } & The Russians & Other nationalities \\
\hline Russian citizens & 79.4 & 65.4 \\
Residents of own city, village & 73.6 & 63.1 \\
$\begin{array}{l}\text { Residents of own region, } \\
\text { oblast, Republic }\end{array}$ & 76.8 & 70.7 \\
$\begin{array}{l}\text { Representatives of my ethnos } \\
\begin{array}{l}\text { Representatives of my } \\
\text { generation }\end{array}\end{array}$ & 69.3 & 63.8 \\
$\begin{array}{l}\text { Representatives of my } \\
\text { profession }\end{array}$ & 61.2 & 54.1 \\
$\begin{array}{l}\text { My coreligionists } \\
\text { People of similar incomes }\end{array}$ & 49.7 & 44.8 \\
$\begin{array}{l}\text { People close to my political } \\
\text { views }\end{array}$ & 43.9 & 50.8 \\
\hline \hline
\end{tabular}

As highly marked ethnic identification usually considered as the obstacle for formation of civic identity, we found necessary to study the influence of actual ethnic identity for the formation of civic and religion identity. We divided all respondents in categories by the strength of manifestation of ethnic identity. The base for division was the question: "Do you fell proximity with representatives of your ethnos? In which extent?". Respondents, indicated own proximity as "in considerable extent" and "in a small extent" arranged the first group with highly marked ethnic identity, and whose, who indicated "rather are" and "in a small extent" arranged the second group with unmarked ethnic identity. Further we analysed some aspects of civic and religion identity in two groups. All revealed group variations statistically valid (Mann - Whitney U-test).

The obtained data let us conclude, that the formed ethnic identity is not a barrier for development of civic identity. Thus, in sum $94.1 \%$ of respondents with marked ethnic identity agree with the statement "I am the Russian citizen" ("rather agree" - 19.9\% and "absolutely agree" - 74.2\%). The majority of respondents with unmarked identity consider themselves as Russians (by two positions $27.6 \%$ and $56.6 \%$ correspondingly). In sum $89.9 \%$ of respondents with marked identity and $69.9 \%$ of respondents with unmarked identity. So we conclude about formed all-Russian civic identity of both groups.

We should point out, that for the most part of population the civic identity closely connected with the understanding of the proud and happiness about citizenship. In sum, $87.8 \%$ and $83.4 \%$ of respondents with marked identity "absolute agree" and "rather agree" with the statement. Such statement share 70.0\% and 64.3\% of respondents with unmarked identity correspondingly. People with unmarked identity found difficult to evaluate the extent of the proud and happiness about the Russian citizenship, we suppose it testifies about indifference and variety of their feelings.

Thus, we see that civic identity of respondents in both groups evidently manifested. Differences connected with the importance of this or that type of identity, which in whole if higher in groups of people, feeling proximity with own ethnos.

The relation of respondents of both groups to religion and estimation of own religion is not so clear: $68.6 \%$ of respondents with marked identity consider themselves as representatives of own religious group ("absolutely agree" - 36.5\%, "rather agree" - 48.4\%) and 48.4\% with unmarked identity (20.6\% and $27.8 \%$ correspondingly). Many of them are proud by their religion (in sum, $60.2 \%$ with marked identity and $42.4 \%$ with unmarked identity) and glad to practice religion (in sum, $54.1 \%$ and $37.0 \%$ correspondingly).

At the same time, the less part of respondents agree, that the religion is an important part of the life: in sum by positions "absolutely agree" and "rather agree" $54.2 \%$ of respondents with marked identity and $36.3 \%$ - with 
unmarked identity. Estimation of the statement "I try to be scrupulous in rules of my religion in everyday life" varies: only $42.6 \%$ of respondents with marked identity agreed with the statement, and $29.5 \%$ of respondents in the group with unmarked identity disagreed. Thus, the less number of people follow religious requirements in everyday life while formally identity themselves in religious sense.

Our data show that at present religion is the less important factor of social differentiation, than the ethnic and civic belonging. However, in whole, religious identity is considerable for people of marked ethnic identity.

Analysis of identification matrix of respondents in the groups confirms the revealed tendencies (Table 2).

TABLE 2: Distribution of answers to the question

"Do you fell proximity with representatives of your ethnos? In which extent?" in groups, \%.

\begin{tabular}{lcc}
\hline \hline \multicolumn{1}{c}{ Community } & $\begin{array}{c}\text { Respondents with } \\
\text { marked ethic } \\
\text { identity }\end{array}$ & $\begin{array}{c}\text { Respondents with } \\
\text { unmarked ethnic } \\
\text { identity }\end{array}$ \\
\hline Russian citizens & 43.9 & 80.9 \\
Residents of own city, village & 34.0 & 80.0 \\
$\begin{array}{l}\text { Residents of own region, } \\
\text { oblast, Republic }\end{array}$ & 31.6 & 76.1 \\
$\begin{array}{l}\text { Representatives of my ethnos } \\
\begin{array}{l}\text { Representatives of my } \\
\text { generation }\end{array}\end{array}$ & 24.8 & 63.3 \\
$\begin{array}{l}\text { Representatives of my } \\
\text { profession }\end{array}$ & 21.0 & 51.9 \\
My coreligionists & 9.5 & 49.8 \\
$\begin{array}{l}\text { People of similar incomes } \\
\text { People close to my political } \\
\text { views }\end{array}$ & 10.5 & 45.7 \\
\hline \hline
\end{tabular}

According to the data of the table 2, respondents with marked identity in a great extent feel proximity with other social communities. The majority of respondents in the group of marked identity feel proximity with citizens of Russia, residents of their region or place of living, co-believers, and representatives of the same profession, social status and political views. At the same time, respondents with unmarked identity often chose variants "in a small extent" and "do not feel proximity".

\section{Conclusion}

The study demonstrates that the most spread form of identity is the civic one. At the same time, actualized ethnic identity is not the obstacle for the proximity with the community of the Russian citizens. In addition, we revealed that different identities not only do not compete with each other and not alternative, but, opposite, they are interdependent and provide closer integration of a personality into social communities. We revealed the correlation between ethnic and religious identity, while the last one is not so important for respondents as, for example, the ethnic or civic identities. We approved that religious factor have the most influence for representatives of non-Russian ethnic groups, than to the Russian population of the observed regions.

\section{Acknowledgement}

This work was supported by the Ministry of Education and Science of the Russian Federation, the State Order for the scientific research "Civic and ethic identities in the system of maintenance of social security among population in border territories of Russia" [№28.1475.2014K]. 


\section{References}

[1] E. V. Eryomina, 'Regional identity in the context of sociological analysis', In Regionology, 2011, vol. 3

[2] L. M. Drobizheva, 'National-civic and ethnic identity: problems of positive combination', In The Russia reforming, 2008, vol. 7.

[3] O. A. Bogatova, 'Ethnic, religious and civic identity in a region', In Regionology, 2016, vol. 3

[4] H Tajfel and C. Turner, 'The Social Identity Theory of Intergroup Behavior', In Psychology of intergroup relations. Worchel S, Austin WG (Eds.). Chicago: Nelson-Hall:7-24, 1998.

[5] J. E. Marcia, 'Development and validation of ego-identity status', In Journal of Personality and Social Psychology, 1996, 3:551-558. https://doi.org/10.1037/h0023281

[6] L. Hjelle and D. Ziegler, Personality Theories: Basic Assumptions, Research, and Applications, 3th ed..McGrowHill, 1992.

[7] Ch. Cooley, 'Human nature and social order'. Moscow: House of intellectual book. Critical Psychology in Changing World: 741-755, 2000.

[8] E. Goffman, Frames analysis: essay about organization of ordinary experience, Moscow, 2003, p.p. 577.

[9] G. Mead, Selected works. Institute of Scientific Information on Social Sciences: 290. Moscow: RAN INION, 2009.

[10]L. M. Drobizheva, 'Ethnic solidarity, civic consolidation and perspectives of interethnic harmony in Russian Federation', In Social sciences and the modernity, 2014, vol. 1.

[11] V. A. Avksentyev and B. V. Aksyumov, 'Portfolio of the youth identities in the Russian South in conditions of civilization choice', In Sociological research, 2010, vol. 12.

[12] S. G. Maximova, G. S. Avdeeva, O. E. Noyanzina, D. A. Omelchenko and N. Yu. Atyasova, 'Civic and ethnic identity of population of border regions of Russia: peculiarities of contemporary condition, factors and actual problems of formation', In The Altai State University Issues, 2015, vol. 3-1 (87), p.p. 31-35.

[13] L. V. Klimenko, 'Indentity of the Adygei Republic: correlation between all-Russian, regional and ethnic components', In Journal of sociology and social anthropology, 2011, N. 1, vol. 14.

[14] O. E. Noyanzina, M.B. Maximov, O. V. Hodorenko, O. V. Surtaeva and M.E. Vozilkina, 'Multinationlity of contemporary Russian society as a base for formation of ethnic identity of population in Russia', In The Altai State University Issues, 2015, vol. 3-1 (87), p.p. 36-42.

[15] A.G. Sanina, 'Formation of Russian identity: civic-governmental approach', In Sociological research, 2012, vol. 12.

[16] A.A. Gorbunova, O.V. Borisova and S.G. Maximova, 'Civic and ethnic identity in estimations of population of the Altai region', In Sociodynamics, 2015, vol. 12.

[17]P. Sztompka, Trust: A Sociological Theory, Cambridge: Cambridge University Press, 1999.

[18]E. N. Danilova, 'Through the prism of social identities', The Reforming Russia, Annual book 2004, Moscow, 2004, p.p. 204-241.

[19] The Project "ESS-Russia", Sociological survey in 150 settlements in all subjects of the Russian Federation, $\mathrm{n}=$ 2400. [Online], Available: www.europeansocial survey.org. 